\title{
Studies on changes in hematological and biochemical parameters in smokeless tobacco (Gutka) chewing auto drivers in Nellore district of Andhra Pradesh, India
}

\section{P.J aganmohan* and A. Phaninanatha Sarma}

Harrison Institute of Biotechnology, Shrimp Care Unit, Ramamurthy Nagar, Nellore-524001 (A.P.), INDIA

*Corresponding author. E-mail: pjaganbio@gmail.com

Abstract: The present study was designed to evaluate the effect of Smokeless tobacco on some biochemical and haematological parameters. It was observed that hematological parameters of Autodrivers including hemoglobin content, white blood cell and leukocyte counts were higher in Gutka consumers than in controls, where as monocytes and basophils counts were lower. Higher biochemical parameters like serum cholesterol, glucose and protein were observed in blood samples of Gutka consumers. Decrease in serum protein levels and remarkable increase in Serum cholesterol and glucose levels were observed in Gutka consumers when compared to controls. There existed considerable difference among different hematological and biochemical parameters of gutka chewers when compared to controls.

Keywords: Gutka powder, Jardha, Cholesterol, Smokeless tobacco

\section{INTRODUCTION}

Although it has dangerous effect on human health the tobacco as drug substance has been used throughout the world (Benowitz et al., 1988; Idris et al., 1998). Nicotine is used in different forms including smoking and smokeless tobacco (Benowitz et al., 1988). Most of the educated and uneducated young peoples are addicted to Gutka powder in India. For the preparation of Gutka nicotine tobacco is used. Tobacco leaves are powdered and mixed with lime (Javed et al., 2008). This mixture is packed in $9 \mathrm{~g} /$ packet and sold in local groceries. The immediate availability and the low price give rise to high consumption of chewing tobacco. Although never been studied before, prevalence of smokeless tobaco usage among the auto drivers is thought to be highly common (Shahid et al., 2005). This simply readily available powder is placed between lower labile mucosa and gingival for about 5-10 min and then spit out. The mixture is used (7-10 times per day) 2-3 g for each time. In the present study an attempt has been made to evaluate the effect of smokeless tobacco (ST) (Gutka) on hematological and biochemical parameters in Gutka chewers in Autodrivers of Nellore district, Andhra Pradesh.

\section{MATERIALS AND METHODS}

Blood samples were collected from persons of different age groups (ranging 16-40 years) of autodrivers who were consuming Gutka 10-12 g/day for a period of 4-5 years and from the drivers who did not take any smokeless powder (controls). The blood samples were used for hematological and biochemical studies. The blood samples were centrifuged at $2000 \mathrm{rpm}$ for $20 \mathrm{~min}$ and plasma was separated. Hematological parameters such as hemoglobin, red blood cells and leukocyte types (white blood cells, neutrophils, lymphocytes, and basophils) were estimated with an automatic electronic blood count analyzer (Cell Dyne 3700, Abbott diag. USA). The biochemical parameters like serum cholesterol was estimated by the method of Allain et al. (1974), blood glucose and serum protein were measured by the methods given by Tinder (1969) and Lowry et al. (1951) respectively. Data was statistically analyzed.

\section{RESULTS AND DISCUSSION}

Gutka consumers and control group's erythrocyte parameters and leukocyte cell counts are listed in Table 2. In Smokeless tobacco (Gutka) consuming auto drivers, hemoglobin percentage was significantly lower than the control (Table 2). But this trend was reverse in case of white blood cell count (WBC). The WBC counts increased from 7.4 to 9.8 in ST consumers compare to the control (Table 2). The total leukocytes counts including neutrophils and lymphocytes counts also increased than control ST consumers and the results were similar with the previous reports (Effraim et al., 2000; Rajsekhar et al., 2007). The lymphocytes counts also increased with ST consumers. With increasing age of ST consumers, RBC count decreased (Table 2). Similar reports were made by Metin et al. (2004) and Rajasekhar et al. (2007) who 
Table 1. Effect of gutka on hematological parameters.

\begin{tabular}{|c|c|c|c|c|c|c|c|c|c|c|c|c|c|c|}
\hline \multirow[t]{2}{*}{ Parameter } & \multicolumn{14}{|c|}{ Age } \\
\hline & Control & 16 & 18 & 20 & 22 & 24 & 26 & 28 & 30 & 32 & 34 & 36 & 38 & 40 \\
\hline $\mathrm{Hgb}(\mathrm{gm} / \mathrm{dl})$ & 15.52 & 8.4 & 10.4 & 10 & 12.6 & 13 & 12 & 12.5 & 10 & 9.2 & 8.4 & 11.5 & 12.0 & 12.15 \\
\hline WBC (k/ l) & 6.8 & 9.6 & 9.8 & 8.6 & 8.4 & 7.8 & 7.4 & 7.7 & 9.0 & 9.4 & 9.2 & 9.4 & 9.6 & 9.8 \\
\hline Neutrophil (\%) & 54.0 & 68 & 66 & 64 & 58 & 58 & 62 & 64 & 58 & 56 & 58 & 58 & 60 & 64 \\
\hline Lymphocyte (\%) & 32.3 & 30 & 29.15 & 30 & 32 & 40 & 37 & 38 & 38 & 40 & 41 & 40 & 39 & 40 \\
\hline Basophil (\%) & 1 & 0 & 0 & 0 & 0 & 0 & 0 & 0.2 & 0.4 & 0.2 & 0 & 0 & 0 & 0 \\
\hline RBC (M/ 1) & $4.5-5.0$ & 3.0 & 3.0 & 3.6 & 4.0 & 4.6 & 4.1 & 4.0 & 4.0 & 3.8 & 4.1 & 3.8 & 3.6 & 3.2 \\
\hline
\end{tabular}

* All the values are the mean of triplets

Table 2. Effect of gutka on biochemical parameters.

\begin{tabular}{|c|c|c|c|c|c|c|c|c|c|c|c|c|c|c|}
\hline \multirow[t]{2}{*}{ Parameter } & \multicolumn{14}{|c|}{ Age } \\
\hline & Control & 16 & 18 & 20 & 22 & 24 & 26 & 28 & 30 & 32 & 34 & 36 & 38 & 40 \\
\hline $\begin{array}{l}\text { Serum Proteins } \\
(\mathrm{g} / \mathrm{dl})\end{array}$ & $6.8-8.0$ & 6.6 & 6.7 & 6.5 & 6.6 & 6.5 & 6.2 & 5.8 & 5.6 & 5.8 & 6.3 & 6.2 & 6.2 & 6.3 \\
\hline $\begin{array}{l}\text { Blood glucose } \\
(\mathrm{mg} / \mathrm{dl})\end{array}$ & $80-82$ & 66 & 72 & 86 & 82 & 86 & 84.2 & 85 & 90 & 104 & 104.6 & 104.2 & 105 & 103.5 \\
\hline $\begin{array}{l}\text { Cholesterol } \\
(\mathrm{mg} / \mathrm{dl})\end{array}$ & 130.5 & 136 & 144 & 152 & 145 & 196 & 185 & 182 & 164 & 180 & 184 & 182 & 184.4 & 188 \\
\hline
\end{tabular}

* All the values are the mean of triplets

observed that Mardas powder and Jardha powder consumers respectively (smokeless tobacco) have increased WBC counts (Murat et al., 2006; Rajsekhar et al., 2007), and decreased neutrophils lymphocytes and basophils. Some other studies reported that leukocytes counts were significantly high in ST users (Friedman et al., 1972; Metin et al., 2004; Sopori and Kozak, 2004; Murat et al., 2006). The effect of smokeless tobacco on biochemical parameters studied is shown in Table 2. The higher level of serum cholesterol and blood glucose, low serum protein levels in smokeless tobacco consumers might be due to the smokeless tobacco the results were in consonance with previous reports (Murat et al., 2006; Rajsekhar et al., 2007). Thus, from the present study it can be concluded that, smokeless tobacco is showing differential adverse events on the hematological and biochemical parameters of Auto drivers.

\section{REFERENCES}

Allain, C.C., Poon, L.S., Chan, C.S.G., Richmond, W. and Fu, P.C. (1974). Enzymatic determination of total serum cholesterol. Clin. Chem., 20 (4): 470-475.

Benowitz, N.L., Porchet, H., Sheiner, L. and Jacob, P. (1988) Nicotine absorption and cardiovascular effects with smokeless tobacco use: Comparison with cigarettes and nicotine gum. Clinical Pharmacol. Therapeutics, 44: 23-28.

Effraim, K.D., Modu, S. and Hamzah, H.G. (2000). Effect of crude garlic on nicotine induced hyperglycaemia and hyperlipidemia in rats. Afr. J. Biomed. Res., 3:125-127.

Friedman, G.D., Siegelaub, A.B., Seltzer, C.C., Feldman, R. and Collen, M.F. (1973). Smoking habits and the leukocyte count. Arch. Environ. Health, 26: 137-143.

Idris, A.M., Ahmed, H.M. and Malik, M.O. (1998). Toombak dipping and cancer of the oral cavity in the Sudan a case control study. Cancer, 63: 477-80.

Javed, F., Altamash, Md., Klinge, B. and Engström, P. (2008) Periodontal conditions and oral symptoms in gutkachewers with and without type 2 diabetes. Acta 0 dontologica Scandinavica, 66(5): 268-273.

Lowry, O.H., Rosebrough, N.J., Farv, A.L. and Randall, R.J. (1951). Protein measurement with Folin-Phenol reagent. J . Biol Chem., 193: 265 - 275

Metin, K., Erdogar, O., Lihami, Y., Fatma, I. and Ergul, B.K.S. (2004). The investigation of the effect of Maras's powder (smokeless tobacco) on hematological parameters. Turk J Haematol., 21(3): 131-136.

Murat, A., Hasan, C.E., Mustafa, C., Ciragil, P. and Mustafa (2006). Comparison of effects of smoking and smokeless tobacco Maras powder use on humoral immune system Parameters. Med of Infl., 14: 1-4.

Rajsekhar, G., Ramgopal, M., Sridevi, A. and Narasimha, G. (2007). Some hematological and biochemical parameters in smokeless tobacco (Jardah) chewers. Afr. J Biotech., 6 (1): 53-54.

Shahid, A., Sonia, A.W., Jennifer, S., Helen, S., Sohrab, B., Manu, S. and Naresh, K. Sharma (2005). A comparison of attitudes and practices of gutka users and non-users in Chitrakoot, India. A Pilot. Primary D ental C are, 12(1): 5-10.

Sopori, M.L. and Kozak, W. (1998). Immunomodulatory effects of cigarette smoke. J . Neuroimmunol., 83: 148-156.

Trinder, P. (1969). Determination of glucose in blood using glucose oxidase with an alternative oxygen acceptor, Ann. Clin. Biochem., 6: 24-25 